\title{
Solusi Pendidikan Agama Islam Mengatasi Kenakalan Remaja Pada Keluarga Broken Home
}

\author{
Mizanul Hasanah ${ }^{1}$, Muhammad Anas Ma`arif ${ }^{2}$ \\ Institut Pesantren Kh. Abdul Chalim Pacet Mojokerto Indonesia \\ e-mail: mizanulhazanah@gmail.com,anasdt16@gmail.com
}

Submitted: 03-03-2021 Revised : 11-04-2021 Accepted: 23-05-2021

\begin{abstract}
Starting from the writer's anxiety with the spread of violence and social deviation as well as the social behavior of the future young generation today. Several factors that really stand out are the result of internal influences, namely family. Most children in their teens show signs of deviance and rebellion, whether overt or secretly. The author is well aware that many other factors influence these things. However, juvenile delinquency treatment is often found due to the broken home factor. In this case, the family has an important role in creating children who have good morals in the future. One of them is by instilling good values in children, namely with Islamic religious education from an early age and even since childhood. The approach used is descriptive qualitative with the interview method. Informants are the parents or guardians of the student. The purpose of this paper is to find out how parents teach religious education, what are the supporting and inbibiting factors of Islamic religious education and the best solutions in Islamic religious education in broken home families
\end{abstract}

Keywords: Islamic Education, juvenile delinquency,broken bome

How to Cite Hasanah, M., \& Ma`arif, M.A (2021). Solusi Pendidikan Agama Islam Mengatasi Kenakalan Remaja Pada Keluarga Broken Home. Attadrib: Jurnal Pendidikan Guru Madrasah Ibtidaiyah, 4 (1), 39-49. doi:

\section{PENDAHULUAN}

Islam sebagai agama yang paling banyak pemeluknya di Indonesia. Mayoritas pemeluknya tersebar merata di seluruh penjuru Nusantara (Komariah, 2019). Salah satu ajaran agama islam yang merupakan sunnah rasulullah SAW adalah menikah. Menikah merupakan ibadah penyempurna iman seorang muslim. Jika belum menikah maka belum sempurna iman seorang muslim tersebut. Ajaran-ajaran tersebut, Islam menuntun manusia untuk mengangkat harkat dan martabatnya agar memperoleh kebahagian di dunia dan akhirat. Mengingat pentingnya pendidikan, Islam memberikan konstribusi yang besar dalam upaya menyiapkan manusia sejak dini menjadi insan paripurna yang memiliki keimanan, keilmuan dan akhlakul karimah yang tinggi, yang nantinya dapat mengembangkan dan memajukan agama, bangsa dan negaranya melalui ilmu yang dimilikinya (Rofi'ah, 2020; Zulaikhah et al., 2020).

Keluarga merupakan pembentuk utama karakter tersebut sekaligus menjadi faktor pendukung terciptanya ajaran-ajaran tersebut melalui pemebentukan akhlak seseorang. Keluarga merupakan bagian penting dalam hidup seorang manusia. Sejak lahir yang paling dekat dikenal oleh manusia adalah anggota keluarga, baik ayah, ibu, saudara laki-laki, saudara perempuan, kakek, nenek, dan anggota lain di dalam senuah keluarga. Pada dasarnya manusia tidak dapat hidup sendiri karenanya butuh figur keluarga di dalamya (Baharun, 2016a).

Setiap orang dalam keluarga memiliki tugas dan peran masing-masing. tugas orang tua adalah mengurus dan mendidik anak-anak, baik di dalam maupun di luar rumah. Mengajarkan 
tata cara, adab, dan perbuatan yang baik dan tidak baik dilakukan karena anak merupakan titipan Allah SWT yang harus diberi petunjuk hidup di dunia, diberikan kasih dan sayang, dipenuhi segala kebutuhan lahiriah maupun batiniahc(Chalim et al., 2020; Hasanah, 2020).

Orang tua berperan sepenuhnya dalam mendidik anaknya. Tentunya selain pendidikan yang di dapatkan oleh anak selain di sekolah. Pengetahuan yang anak dapatkan di sekolah bukan hanya pengetahuan umum namun juga pengetahuan agama Islam (Nurulloh et al., 2020). Hal ini lah yang menjadi perhatian khusus bagi orang tua untuk memiliki tanggung jawab lebih untuk urusan pendidikan anak. Jika anak tidak dikenalkan dengan pendidikan agama islam maka orang tua akan kehilangan kesempatan menuai pahala dan kehidupan anak tidak berjalan baik khususnya seorang muslim yang mana pendidikan agama islam merupakan pedoman hidup bagi umat Islam (Ma'arif \& Cahyani, 2019).

Pendidikan agama merupakan pendidikan dasar yang wajib diberikan oleh orang tua sejak kecil. Hal tersebut mempertimbangan baik dan buruknya pada karakter anak. lembaga pendidikan yang telah dipercayakan orang tua juga tak cukup. Mengandalkan guru yang berada di sekolah, peran guru sebagai pendidik juga tak cukup untuk membentuk karakter anak, karena pusat pendidikan pertama kali yang dikenal anak sejak ia lahir adalah keluarga (Noer \& Sarumpaet, 2017). Karena itu pendidikan agama tak boleh dilewatkan bagi setiap anak. dalam hal ini tugas orang tua sangatlah penting. Kebiasaan yang baik dalam diri anak didik yang tampak pada lingkungannya merupakan faktor yang berasal dari didikan orang tua. Perangai yang baik dari si anak mencerminkan suasana yang baik dalam keluargnya. Tugas lingkungan rumah tanggalah dalam hal ini keluarga yang dapat membina pendidikan ini (H. Tahang, 2010).

Manusia dalam upaya memelihara kelanjutan hidupnya, mewariskan berbagai nilai dan norma setiap generasinya. Alat memeliharan kelanjutan hidup tersebut adalah pendidikan Islam. fungsi utama dari pendidikan agama sebagai pewaris setiap generasinya adalah memanusiakan manusia dalam rangka mewujudkan budaya nya, untuk menghadapi tantangan di masa depan pada zaman yang selalu berubah (Baharun, 2016b; Fajriana \& Aliyah, 2019).

Pendidikan dalam pandangan Islam, berhubungan dengan keimanan seseorang. Sebagiamana contoh dalam kehidupan nyata, membuktikan bahwa pendidikan keimanan yang baik akan menghasilkan akhlak yang baik. Begitu pula sebaliknya. Pendidikan keimanan yang tidak atau kurang baik menghasilkan akhlak yang baik pula. Oleh karena itu, mengingat pentingnya pendidikan islam terutama pendidikan agama Islam yang menjadi penentu karakter seorang anak. Permasalahannya adalah bagaimana peran keluarga dalam memberikan pendidikan agama Islam sejak dini (Djaelani, 2013).

Pendidikan merupakan pemberi corak dalam kehidupan manusia kelak. Warna-warni kehidupan menjadi satu kesatuan sebagai pengangkat derajat manusia kelak. Oleh karenanya, islam kemudian menggariskan bahwa pendidikan adalah salah satu kegiatan yang wajib bagi setiap muslim, baik bagi pria dan wanita yang berlangsung sepanjang hayat. Islam juga mengajarkan kepada umatnya, bagi siapa saja yang ingin kebahagian dunia dan akhirat hendaklah selalu berproses menuntut ilmu. Menuntut ilmu adalah kegiatan yang berlangsung sepanjang hayat tanpa batas waktu dan usia(Hamzah, 2015).

Bagi orang tua mendidik anaknya adalah suatu yang tak dapat dihindari, Karena ia adalah kodrat. Dalam doktrin Islam, peran ini sangat gamblang dijelaskan oleh Allah dalam Al-qur'an, juga Hadist bahwa orang tua adalah pihak yang paling bertanggung jawab terhadap pembinaan dan pendidikan anakanak mereka. Dalam surat At-Tahrim ayat 6 Allah berfriman: "Wahai umat yang beriman, peliharalah dirimu dan keluargamu dari ancaman api neraka". Demikian juga hadist Nabi, "Tiap-tiap anak dilabirkan dalam keadaan fitrah, maka kedua orangtuanyalah yang menjadikan mereka Yahudi, Nasrani dan Majusi". 
Setiap orang tua tentu mendambakan keluarganya bahagia, suatu keluarga yang setiap anggotanya mampu memahami, menghayati dan merealisasikan fungsi keluarga sesuai dengan kedudukannya masing-masing. Diantara fungsi keluarga, selain fungsi rekreatif, protektif, ekonomi, sosial, dan reproduktif selain itu juga mendidik anak dengan mendidik edukatif serta menanamkan pemahaman dan pengalaman tentang keagamaan (religius) . Keluarga merupakan sarana utama dan pertama dalam mendidik serta menanamkan pemahaman dan pengalaman keagamaan (Lestari et al., 2021).

Pendidikan agama Islam merupakan usaha sadar dan terencana untuk menyiapkan peserta didik dalam meyakini, memahami, menghayati dan mengamalkan agama Islam melalui kegiatan bimbingan, pengajaran atau latihan dengan dibarengi tuntutan untuk menghormati penganut agama lain hubungannya dengan kerukunan umat beragama, sehingga terwujud kesatuan dan persatuan bangsa. Dengan demikian berbicara tentang Pendidikan Agama Islam dapat dimaknai dalam dua pengertian, yaitu: sebagai proses penanaman ajaran Islam dan sebagai bahan kajian yang menjadi proses itu sendiri (Masnunah, 2018).

Seyogyanya pendidikan agama islam adalah pendidikan utama yang harus dipelajari guna mencapai kebahagian dunia dan akhirat. Hal ini menjadi poin penting bahwa kebradaan pendidikan agama sangat menentukan kehidupan di masa depan. Maka, orang tua wajib mengusahkan anak-anak mendapatkan pendidika terbaik dimulai dari orang tuanya. Nilai-nilai yang terkandung gunanya adalah menghasilkan generasi-generasi yang beragama dan sesuai tuntunan agama islam (Surur, 2018).

Sebagaimana yang telah dipaparkan di atas, maka penting dilakukan penelitian pada anak usia remaja. Dalam hal ini difokuskan pada anak usia 12-15 tahun pada jenjang SMP. khusunya keluarga yang mengalami broken home yang mengalami perceraian dan pisah ranjang atau tidak ada status yang jelas. Hal yang menarik yang ingin penulis teliti adalah bagaimana cara mengajarkan Pendidikan Agama Islam pada keluarga broken home, apa saja faktor penghambat dan pendukung Pendidikan Agama Islam dalam keluarga broken home, dan bagaimana cara memecahkan masalah yang terjadi dalam mengajarkan Pendidikan Agama Islam pada keluarga broken home.

\section{METODE}

Jenis penelitian ini merupakan penelitian kualitatif dengan pendekatan kualitatif deskriptif. Kehadiran Peneliti Dalam penelitian ini, peneliti bertindak sebagai pengumpul data dan sebagai instrumen aktif dalam upaya mengumpulkan data-data di lapangan (Sugiyono, 2014). Karena penelitian ini meneliti kasus pada satu keluarga sehingga peneliti hanya memfokuskan untuk mewawancari satu keluarga tersebut. dalam keluarga tersebut terdapat Ibu, Bapak sambung anakanak, anak-anak dari ibu yang berangkutan.

Sedangkan instrumen pengumpulan data yang lain selain manusia adalah berbagai bentuk alat-alat bantu dan berupa dokumen-dokumen lainya yang dapat digunakan untuk menunjang keabsahan hasil penelitian namun berfungsi sebagai instrumen pendukung, oleh karena itu kehadiran peneliti secara langsung di lapangan sebagai tolak ukur keberhasilan untuk memahami kasus yang diteliti, sehingga keterlibatan peneliti secara langsung dan aktif dengan informan dan atau sumber data.

\section{Tujuan Pendidikan Agama Islam dalam lingkup Keluarga}

Pendidikan yang dilakukan secara sadar dan terencana dalam menyiapkan peserta didik atau didikan untuk mengenal, memahami, menghayati, hingga mengimani, bertakwa, dan berakhlak mulia dalam mengamalkan ajaran islam dari sumber utama yakni Al Qur'an karim merupakan pendidikan agama islam. Suatu kegiatan yang ditujukan untuk menghasilkan orang-orang beragama yang dikhususkan pada penanaman akhlak dan karakter seseorang (Nugroho, 2018). 
Interaksi di dalam diri manusia memberi pengaruh pada penampilan, sikap tingkah laku dan amalnya sehingga menghasilkan akhlak yang baik. Akhlak tersebut pelru dilatih dengan melakukan amaliyah lain seperti shalat malam, mengkaji Al Qur'an, puasa, bersilaturahmi dengan keluarga dan masyarakat. Semakin sering seseorang melakukan kebaikan dan mencari jalan Allah yakini mencari ridho nya maka akan semakin terpantul cerminan akhlak yang baik pula dengan kegiatan sehari-hari seperti yang telah disebutkan (Setiani, 2013).

Adapun langkah langkah menanamkan pendidikan islam yakni, (1) akidah/iman untk menhasilkan generasi muda masa depan yang tangguh dengan imtaq, (2) ibadah, untuk diajarkan kepada anak anak untuk membangun generasi muda yang komitmen dan terbiasa menjalankan ibadah, seperti shalat, berpuasa, membaca Al qur'an. (3) akhlakul karimah, untuk melahirkan generasi yang bertaqwa, cerdas, berakhlak mulia. Oleh karena itu peran para orang tua dan pendidik baik di lingkungalingkungan sekolah maupun di luar sekolah sangat dibutuhkan. Penanaman pendidikan Islam bagi generasi muda bangsa tidak akan dapat berjalan secara optimal dan konsisten tanpa dibarengi keterlibatan serius dari semua pihak. Oleh karena itu, semua elemen bangsa (pemerintah, tokoh agama, masyarakat, pendidik, orang tua dan sebagainya) harus memiliki niat dan perhatian yang serius agar generasi masa depan (Mutmainah \& Mufid, 2018).

Hal yang menjadi perhatian pada pembelajaran agama islam adalah sebagai berikut: (1) pendidikan islam dilakukan sebagai usaha sadar untuk membimbing, pengajaran atau latihan yang dilakukan secara terencana untuk mencapai tujuan yang hendak divapai yakni menghasilkan generasi dengan akhlakul karimah serta intelektual. (2) membimbing anak dilakukan bertujuan untuk kebaikannya dengan memberikan pemahaman, penghayatan, dan pengalaman ajaran islam. (3) pendidikan agama islam diharapkan menjadi tongak utama membentuk kesalehan pribadi sekaligus untuk membentuk kesalehan sosial. (4) Pendidikan islam diharapkan untuk mengimani ajaran islam sebagaimana tuntunan Rasulullah, dituntun untuk menghormati penganut agama lain dan menjadi alat pemersatu bangsa (Ma'arif, 2017).

Dapat disimpulkan dan diperjelas bahwa Pendidikan Agama Islam adalah Pendidikan yang mengajarkan tentang hal-hal yang menjadi pedoman manusia untuk melakukan segala sesuatu yang memiliki ruang lingkup yang luas, didalam penelitian ini menggukan aspek keimanan, ibadah dan akhlak untuk mengetahui bagaimana cara orang tua mengajarkan tentang pendidikan tersebut.

\section{Sebab-sebab Kenakalan Remaja}

Seringnya salah menberi kesimpulan yang dilakukan masyarakat Indonesia kita pada lingkungan sosial adalah menyalahkan perbuatan atau sikap seseorang kemudian dihubungkan dengan didikan orang tua, atau asal sekolahnya, asal lingkungan, suku, ras, agama dan lain sebagainya (Ahyadin \& Ridwan, 2020). Memang cukup menjadi perhatian penting bagi seorang atau sekelompok orang untuk mengomentari cara atau metode yang dilakukan seorang lainnya. Karena memang perlu diperhatikan cara atau pola didik orang tua pada anak berbeda-beda sesuai karakteristik si anak.

Baik buruknya suatu bangsa yang akan datang sepenuhnya tergantung kepada baik buruknya generasi muda akan datang. Dapat dibayangkan bagaimana masa depan suatu bangsa apabila generasi mudanya mengalami dekadensi moral (Shofwatal Qolbiyyah, 2017). Oleh Karena itu memang diperlukan perhatian khusus untuk menangulangi kenakalan remaja untuk menemukan solusi pemecahan masalah yang terbaik.

Yaqin memaparkan bahwa, siswa yang nakal adalah siswa yang memiliki masalah ketidakmampuan untuk menyesuaikan diri dengan lingkungannya sehingga ia akan melakukan perbuatan-perbuatan yang tidak wajar, padahal sesungguhnya remaja yang nakal adalah manusia yang biasa seperti kita, ia juga memiliki bentuk dasar manusia yakni makhluk yang baik dan selalu memihak pada kebenaran. Oleh sebab itu, maka dapat dikatakan bahwa siswa yang nakal atau 
yang menyimpang, yang hidup secara tidak wajar sebenarnya adalah bukan karena fitrahnya, akan tetapi ada sebab-sebab yang melatar-belakanginya atau mendorongnya untuk berbuat nakal yakni faktor intern dan ekstern. Sehingga dengan demikian, maka perlu adanya proses internalisasi pendidikan agama Islam yang berkelanjutan (Yaqin, 2016).

Adapun beberapa kenakalan remaja, yakni : pertama, Setiap tindakan kenakalan siswa betapapun kecilnya jika tidak mendapatkan penjelasan, teguran, serta kontroling untuk memperbaikinya, akan mengakibatkan seseorang akan terlanjur melakukan yang lebih berbahaya lagi sehingga dapat dikategorikan sebagai tindakan kejahatan. Kenakalan anak sebagai suatu kondisi yang kurang menyenangkan dalam kehidupan sosial banyak jenisnya. Kedua, kenakalan siswa yang menyentuh atau berkaitan dengan masalah material atau kebendaan, seperti pengerusakan gedung. Ketiga, kenakalan yang menyentuh norma-norma agama, sosial, atau adat yang berlaku dalam masyarakat, seperti mencuri, tawuran atau melakukan hubungan seks di luar nikah (Hirdayadi \& Susanti, 2018).

Berdasarkan pemaparan diatas kenakalan remaja tidak semua disebabkan oleh faktor broken home. Namun, seringnya ditemukan kenaklan remaja disebabkan oleh faktor keluarga, didikan orang tua dan bentuk pergolakan emosi atas keputusan perceraian orang tua. Oleh karena itu, dibutuhkannya peran ornag tua untuk selalu mendampingi dan memberi pengertian pada anak dan tak lupa memberi kaish sayang agar si anak tidak merasa ada yang hilang. Bentuk pemberontakan tersebut bisa saja melalui merugikan diri sendiri, orang lain, bahkan keluarga sendiri. Penananaman nilai agama dan moral sangat dibutuhkan anak dalam tumbuh kembangnya.

\section{Keluarga Broken Home}

Broken home adalah "keretakan di dalam keluarga yang berarti rusaknya hubungan satu dengan yang lain di antara anggota keluarga tersebut. Hurlock dalam tulisannya menjabarkan, Broken Home merupakan kulminasi dari penyesuaian perkawinan yang buruk dan terjadi bila suami dan istri sudah tidak mampu lagi mencari cara penyelesaian masalah yang dapat memuaskan kedua belah pihak. Perlu disadari bahwa banyak perkawinan yang tidak membuahkan kebahagiaan tetapi tidak dia akhiri dengan perpisahan. Permasalahan tersebut dikarenakan perkawinan dilandasi dengan suatu pertimbangan agama, moral, kondisi ekonomi dan alasanalasan yang lain. Perpisahan atau pembatalan perkawinan dapat dilakukan secara hukum maupun dengan diam-diam dan kadang ada juga kasus dimana salah satu pasangan (suami, istri) meninggalkan keluarganya (Tindagi, 2017).

Dewasa ini banyak contoh keluarga broken home yang memiliki permasalahan yang cukup komplit dan rumit. Tentunya faktor yang melatarbelakangi cukup bervariasi dan kompleks. Tentuya dilihat dari banyak sudut yang berbeda-beda. Antara lain bisa dianalisis menurut pandangan agama yang lebih menekankan berdasarkan nilai-nilai normatif, dan psikologi social sebagai desiplin ilmu terapan, bisa dianalisis berdasarkan pandangan dan teori, demikian juga halnya bila dilihat menurut perspektif socialogis yang lebih bersifat fenomenal dan emperis. Jika dilihat dari sudut pandang yang lebih fenomenal adalah berdampak pada perilaku sosial anak korban broken home yakni cenderung nakal dan menyimpang (Aziz, 2019).

Pada umumnya terdapat sejak usia jenjang tingkat sekolah menengah pertama hingga usia18 pada kususnya bukanlah suatu hal baru. Namun hal tersebut menjadi tertarik untuk dibahas karena anak-anak korban broken home perilaku-perilaku mereka sudah menggelisahkan para guru, sehingga menjadi anak yang bermasalah di sekolahnya. Kondisi rumah tangga yang broken sering anak-anak mengalami depresi mental (tekanan mental), sehingga tidak jarang anak-anak yang hidup dalam keluarganya yang demikian mengalami pemberontakan, pergolakan hebat dalam diri, bahkan terkadang melampiasakan emosi yang berlebih pada objek lain.

Kondisi tersebut tidak akan mungkin muncul secara mendadak apabila tidak ada faktor yang dibawa si anak. pengaruh tersebut bisa dibawa karena permasalahan ketidakharmonisan 
keluarga. Sehingga ada emosi yang berkecamuk dalam dirinya. Menurut perspektif islam, untuk mengkaji perilaku social anak di lingkungan sekolah, Islam sebagai ajaran, sebagai konsep normative, masalah tersebut harus dikaji terlebih dahulu akar masalah sebagai penyebab timbulnya perilaku-perilaku sosialnya yang dianggap sebagai sebuah masalah sosial.

Keluarga terdiri dari Bapak, Ibu, dan anak. Bapak dan ibu memiliki kedudukan sebagai pemimpin dan waki pemimpin pada anak didiknya yaitu anaknya. Pola didikan, sistem pembinaan, nuansa kehidupan, perilaku sosial dan karakter anak ketika berinteraksi di luar dengan kelompok kelompok yang lebih besar seperti sekoah, tempat bermain, bekerja, organisiasi dan lainnya. Bertolak dari dasar pemikiran bahwa perilaku social anak dalam kehidupan social yang lebih luas di masyarakat termasuk dalam lingkungan sekolah, adalah sangat ditentukan oleh bagaimana bentukan dan binaan dari kedua orang tuanya dalam keluarga (Usu et al., 2020).

Bapak dan Ibunya sebagai pemimpin, sudah barang tentu sesuai dengan kedudukannya masing-masing punya tugas untuk mendidik dan membina dengan penuh tanggungjawab karena setiap pemimpin dalam hal ini sebagai orang tua, akan diminta pertanggungan jawab di hadapan Allah kelak. Semua orang tua kelak akan allah minta pertanggung jawaban atas amanah yang allah berikan yaitu mendidik anaknya. Tugas seorang orang tua juga membekali anak-anaknya dengan berbagai macam metode.

Lebih jauh lagi, konsep- konsep hidup social yang dituntun oleh para orang tua yang seperti ini, mungkin tidak terlalu banyak pengaruhnya menjadi sikap hidup anak, selama kedua kedua orang tuanya belum mampu mengamalkannya, menunjukkan, atau menginternalisasikannya dalam kehidupan nyata di hadapan anak-anaknya dalam keseharian hidup keluarganya. Adapun interaksi sosial dalam lingkungan keluarganya, antara satu sama lain menyebabkan seorang anak menyadari akan dirinya sebagai makhluk social. Sebagai mahluk sosial suatu saat akan mengerti betapa pentingnya kehidupan sosial. Dan yang mempengaruhi hal tersebut melalui kehidupan rumah tangga.

Rumah tangga merupakan tempat peletakan batu pertama bagi seorang anak yaitu berupa keimanan dan ketaqwaan yang kokoh sebagai fundamen hidup. Kalau setiap rumah tangga sudah memulai membina anak-anaknya sesuai dengan konsep-konsep keislaman, berusaha secara berkelanjutan menanamkan nilai-nilai aqidah, ibadah, dan nilai-nilai akhlaq yang mulia, sebagai wujud tanggung jawab yang wajib dimainkan oleh kedua orang tuanya dalam keluarga, maka akan terwujud sebuah keluarga sakinah dan keluarga sakinah merupakan cikal bakal terbentuknya hubungan social yang lebih luas termasuk lingkungan sekolah, terlebih lagi lingkungan masyarakat yang sesuai dengan harapan agama (Ahmad \& Asdiana, 2019). Kalau binaan di dalam rumah tangganya sudah baik, maka kehidupan anak, baik yang berhubungan dengan kehidupan duniawi maupun akhirat juga akan baik (Ariani, 2019).

Permasalahan khususnya di Indonesia adalah banyak anak korban broken home tingkat SMP mengalami tekanan (depresi) mentalnya, umur remaja memang sangat rentan dengan problema sosial terutama karena dilatarbelakangi oleh keluarga tersebut. Sehingga perilakuperilaku mereka menyebabkan banyak guru yang mengeluh dan cukup menggelisahkan karena suka melanggar aturan- aturan sekolah, bicara kasar, suka melawan dan menentang, tidak berakhlaq, tidak bermoral, malas ke sekolah, suka bolos, malas belajar, hilang semangat belajar, suka recok dan caper, suka mengganggu teman dan guru (Widyastuti Gintulangi, Jusdin Puluhulawa, 2019).

Kasus-kasus anak broken home nampak nyata dalam berbagai bentuk penyimpangan sebagaimana yang sudah disebutkan, sehingga perilaku- perilaku mereka sangat mengganggu suasana kelas dan sangat-sangat mengganggu jalannya proses belajar mengajar, perilaku-perilaku mereka memang meresahkan para guru dalam proses belajar mengajar. Oleh karena itu pentingnya pendidikan agama melaui orang tua dibantu dengan lembaga pendidikan serta semangat dari seluruh lapisan masyarakat di lingkungan dalam membentuk karakter seorang anak, 
khusus orang tuanya. Sehingga walaupun keluarga tersebut broken home tidak merusak mental dan rohaniah anak tersebut.

\section{HASIL DAN PEMBAHASAN}

\section{Hasil dan Pembahasan}

Dalam setiap keluarga mempunyai cara yang beragam dalam mendidik anaknya. Dalam keluarga yang utuh mendidik anak akan terasa ringan karena antara pihak Ayah dan Ibu seimbang dan sama sama memberikan pengaruh yang baik. Berbeda dengan keluarga yang retak, tidak utuh atau sering disebut broken home Pendidikan anak akan terasa tidak utuh dan tidak sempurna, meskipun dari Ayah ataupun Ibu sudah berusaha keras untuk mendidiknya. Setelah penulis melakukan penelitian, dibawah ini merupakan paparan bagaimana orangtua mengajarkan Pendidikan Agama Islam pada anaknya khusunya dalam keluarga Broken home.

Setelah dilakukan observasi dan wawancara terhadap ditemukan Pendidikan Agama Islam dalam keluarga Broken home sebagai berikut:

\section{Cara Orang tua mengajarkan Pendidikan Agama Islam}

Setiap keluarga mempunyai cara yang beragam dalam mendidik anaknya. Dalam keluarga yang utuh mendidik anak akan terasa ringan karena antara pihak Ayah dan Ibu seimbang dan sama sama memberikan pengaruh yang baik. Berbeda dengan keluarga yang retak, tidak utuh atau sering disebut broken home Pendidikan anak akan terasa tidak utuh dan tidak sempurna, meskipun dari Ayah ataupun Ibu sudah berusaha keras untuk mendidiknya.

Setelah penulis melakukan penelitian, dibawah ini merupakan paparan bagaimana orangtua mengajarkan Pendidikan Agama Islam pada anaknya khusunya dalam keluarga Broken home. Keluarga ibu AF Merupakan tulang pungung keluarga, karena mata pencaharian terbesar bersumber dari ibu AF. Meskipun ibu AF sudah memilih untuk menikah lagi. Dan sekarang sudah memiliki suami baru. Bu AF tetap ingin bekerja keras memenuhi kebutuhan anak. karena baginya anak ada prioritas utama dan pekerjaannya saat ini tidak mengorbankan waktu untuk keluarga yakni bekerja dari rumah. Beliau mengutarakan bahwa mantan suaminya dulu tidak begitu intens setiap bulan mengirim kebutuhan anaknya. Anak anak lebih dekat dengan bapak barunya. Dan dimanja olehnya. Jika meminta sesuatu keinginan, misal dari pondok minta ini itu selalu dituruti.

Dalam mendidik anaknya khusunya Pendidikan agama Islam beliau langsung mengajari anak tentang shalat, puasa, dan bersikap baik dengan yang lebih tua pada anak-anaknya. Saat ini anaknya sekolah di Pondok Pesantren tahfidz. Sebagaimana yang dipaparkan oleh bu AF:

"Albamdulillah saya bekerja begini tidak mengorbankan perbatian pada anak. dibantu juga dengan bapak baru anak-anak. lagi pula anak-anak lebib dekat dengan bapak baru dibanding bapak kandungnnya. Namun, saya tetap ingatkan untuk selalu komunikais dengan bapak kandungnya. Begitu bu".

Berdasarkan wawancara dengan anak ibu perempuan ibu AF adalah sebagai berikut :

"Ibu ndak pernah memaksa kehendaknya. Namun untuk urusan agama ibu paling cerewet apalagi semenjak pisah dengan bapak. Didikan ibu menjadi lebih erat. Seperti membangunkan untuk shalat subub. Bolak balik mengedor pintu dan mengoyangkan badan kami"

Berdasarkan penuturan bapak baru (suami ibu AF) bahwa cara beliau mendidik anak-anak tidak begitu sempurna. Namun, semua yang dilakukan adalah yang terbaik baginya untuk anakanaknya. Bapak WR, Sangat berharap menitipkan anak-anak di lembaga pendidikan yang terbaik kemudian dibimbing oleh tenaga pendidik yang baik yakni di sekolah.

"Kalo sholat lima waktu saya kadang-kadang mengingatkan. Saya lebih memperbatikan sekolahnya biar dia jadi orang sukses nanti. Biasanya kalo puasa ramadhan anak -anak puasa tapi kadang ada-ada 
saja yang bolong beberapakali. Sekarang pada susah dibilangin, udah pada gedhe-gedhe malah sering gak pada mu nurut. saya ngajarin anak tentang agama paling hal-hal yang kecil aja. Soalmya ilmu saya tentang agama juga tidak, terlalu tinggi. yang penting anak saya bisa ngaji itu aja udah cukup."

Berdasarkan pengamatan peneliti, bahwa ibu AF Mengusahakan segala kemampuannya untuk memberi kebutuhan anak-anaknya. Walaupun saat ini sudah memiliki suami baru. Namun, perasaannya sebagai Ibu tunggal beberapa waktu lalu menjadi motivasi dan kekuata bagi dirinya sendiri untuk tetap bekerja manjadi tulang punggung keluarga. Baginya anaknya tidak boleh kekurangan apapun, baik pengetahuan agama, akhlak, finansial, ekonomi, dan perhatian orang tua kandung. Meski bapak kandungnya tidak berlaku demikian. Namun dibantu oleh bapak WR sebagai pendamping baru yang sangat perhatian akan sekolah anaknya.

\section{Faktor Pendukung dan Penghambat}

Setiap pelaksanaan Pendidikan Agama Islam mempunyai faktor-faktor yang menjadi pendukung dan yang menjadi pendukung. Faktor yang menjadi pendukung merupakan faktor yang memberikan dampak yang baik atau konstruktif. Setiap anak yang dididik pasti tidak akan semudah dan bebas tanpa tantangan. Orang tua harus dapat mempertahankan hal-hal atau faktor-faktor yang menjadi pendukung agar mendidik tentang Pendidikan Agama Islam pun lebih efektif.

Faktor penghambat merupakan hal yang menjadikan anak tidak dapat menerima Pendidikan Agama Islam dan lebih berfokus dengan hal yang lainnya. Faktor penghambat harus sebisa mungkin dikondisikan oleh orang tua agar pelaksanaan Pendidikan Agama Islam tetap berjalan dengan baik. Adapun beberapa faktor yang dapat mempengaruhi, faktor penghambat dan faktor pendukung, dalam orang tua mendidik Pendidikan Agama Islam. Dalam keluarga Ibu AF yang menjadi dominan yaitu sebagai faktor penghambat. Sesuai yang telah diutarakan oleh Ibu AF berikut ini :

"Hambatannya selama ini menurut saya khusunya RY teman sebaya, sering mengajak touring kemana saja sampai Bojonegoro. Pernah sampai jogya. Tapi albamdulilah sejaub ini nggak pernah ketangkep polisi soale berangkatnya malem pulangnya dua hari sesudahnya pagi gitu. Selama ini saya nurutin apa aja kemanan dia, tapi kalo dia seenaknya sendiri ya gimana lagi, dia itu sifatnya nurun bapak kandungnya mirip banget. Kalo TK alhamdulilah nurut kalo sama saya".

Bapak WR memaparkan bahwa tidak ada hambatan apapun mengurus anaknya. Beliau berpesan bahwa beliau bukan bapak kandung dari kedua anak bu AF. Namun, sudah beliau anggap sebagai anak sendiri. Beliau selalu mendidik anaknya dengan penuh perhatian dan kasih sayang. Perhatiannya yang tidak pernah terlewatkan. Dengan hal tersebut dapat menjadi faktor pendukung dalam pendidikan agama Islam. Anak akan lebih mudah untuk mengerti dan mau belajar tentang Agama. Lingkungan keluarga terutama keluarga terdekat yaitu nenek yang selalu memberikan motivasi agar usaha Ibu mendidik anak-anaknya dapat berjalan dengan baik dan sesuai dengan tujuannya.

"Selama ini yang mendukung dia bisa mau sekolah dan belajar dirumah ya dia sendiri, dia kalo nggak semannya sendiri susab dibilangin. Nanti nek saya marabi malah jadi ribut malah bangkang. Faktor lain itu dari perhatian guru-gurunya disekolahan. Kalo faktor penghambatnya ya kalo dia susah dibilangin, semaunya sendiri."

Dapat disimpulkan bahwa faktor pendukung atau pendukung Pendidikan Agama Islam dalam keluarga Ibu AF yaitu Orang tuanya yairtu Ibunya, perhatian dan segala kebutuhan anaknya selalu dipenuhi apapun yang diinginkan selalu dikabulkan. Sedangkan yang menjadi faktor penghambat adalah Lingkungan sekitar dan teman sebaya. Teman sebaya mempengaruhi hal yang negatif karena melakukan sesuatu yang tidak bermanfaat contohnya touring.

\section{Solusi pendidikan islam pada keluarga broken home}


Keluarga yang harmonis merupakan keluarga yang selalu didambakan oleh setiap orang. Suasana tersebut diciptakan untuk kebaikan anggota keluarganya seperti Ayah, Ibu dan yang palng terpenting yaitu seorang anak. Anak adalah fitrah yang telah dititipkan oleh Allah SW'T untuk manusia terutama orang tua agar mendidik dengan sepenuh hati, ikhlas, sabar. Tetapi, akan berbeda halnya ketika didalam keluarga terdapat konflik-konflik atau masalah-masalah. Biasanya masalah tersebut timbul antara Ayah dengan Ibu, atau orang tua dengan anak. Dalam keluarga broken home tentu tidak terlepas dari masalah. Semua yang mengalaminya akan merasakan dan dapat menemukan cara memecahkan masalah tersebut. Keluarga Ibu AF, Ketika masalah telah muncul dalam keluarga beliau memilih untuk menasehati anak-anaknya terutama untuk anak pertamanya RY. Ibu AF memilih menggunakan cara dengan menyentuh hatinya. Selain itu cara yang dilakukannya adalah dengan hentakan atau gertakan yang membangun. Seperti yang telah diutarakan oleh Ibu RM berikut ini:

"Caranya ya dinasehati, kalo baik-baik nggak bisa ya dihertak ditegasi soalnya kalo RY itu harus ditegasin, kalo TK masib bisa nurut. kadang kalo saya udah capek. ngadepin dia. Saya selalu bilang gini sama RY"mas, kamu mau manut nggak sama mamak, kalo masib mau nurut ya yang rajin, kalo mau semaunya sendiri apa mau tinggal sama bapakmu aja sana" mamak tak dirumah aja sama TK adekmu. biasanya kalo dibertake kaya gitu dia mau nurut."

Bapak WR ikut menuturkan sewaktu peneliti mewawancarai beliau. Siakp seorang bapak yang tenang dan lebih santai diutarakan bahwa mendidik anak tidak boleh keras juga tidak boleh terlalu lembut. Harus memperhatikan situasi dan kondisi anak. serta tidak lekas menjudge.

"Saya kasih pengertian, misalnya itu jelek tidak baik. Pada intinya saya kasih tau mana yang baik dan mana yang tidak baik. Di nasehatin juga kalo misalnya bandel. biasanya kalo minta jajan banyak banget. tak surub nabung biar nggake jajan terus. kalo gakmau ngaji kadang saya cari senatu yang bisa buat dia mau rajin lagi ngaji, kayak hadiah ato apa."kalau dia ingin main dengan temannya. Selalu saya sampaikan. Main boleh tapi jangan lupa belajar dan ingat pesan ibumu kalau diluar rumab".

Berdasarkan pengamatan peneliti, ibu AF yang merupakan orang yang pernah bercerai. sangat ingin anaknya tumbuh menjadi pribadi yang lebih baik darinya. Tidak kekurangan satu apapun. Begitu pula dengan bapak baru anak-anak, tidak ingin anaknya merasa di asingkan sebagai anak tiri darinya. Memberikan hadiah merupakan cara untuk membangkitkan semangat anak. Karena mood pada anak yang sebelumnya turun akan kembali stabil kembali bahkan akan meningkatkan mood anak. Tetapi hal tersebut harus dibatas wajar karena ketika anak selalu dibiasakan seperti itu akan menjadi kebiasaan yang buruk. Hal tersebut hanya sebagai perantara untuk mengembalikan kestabilan anak. Setiap anak pasti mempunyai rasa malas dan kemauannya yang tidak stabil. Baik pada usia anak-anak maupun usia Remaja sekalipun. Dengan begitu orang tua harus semaksimal mungkin memkirkan jalan keluar yang tepat ketika melakukan mediasi atau musyawarah pada anaknya.

\section{KESIMPULAN}

Cara orang tua mengajarkan Pendidikan Agama Islam dalam keluarga Broken home. Mengajarkan Pendidikan Agama Islam sejak usia dini, menyekolahkan di sekolahan Islam terpadu, Mengajarkan puasa wajib dan sunnah. Dalam hal akhlak mencontohkan perilaku yang baik, disiplin, sopan santun, kemandirian. menyuruh mengaji, selalu memarahi ketika melakukan kesalahan. Faktor pendukung dan faktor penghambat Pendidikan Agama Islam dalam keluarga Broken home. Faktor motor penghambat vespa yang selalu mengajak untuk pergi touring sehingga waktu untuk di rumah tersita. Perasaan anak yang tidak stabil sehingga anak terkadang merasa jenuh. Permintaan yang kadang tidak terpenuhi seperti meminta HP dengan wajah yang cemberut. Tidak adanya kasih sayang seorang ibu yang bisa mendidiknya dan mengajarkan tentang agama dan tidak ada hubungan yang baik antara ayah dan anak. Tidak adanya seorang ayah dan suasana keluarga yang tidak harmonis. Faktor pendukung Keluarga yaitu Ibu AF yang 
selalu memanjakan dan menuruti semua kemauan anaknya. Selalu memberikan perhatian penuh sehingga menjadi faktor pendukung serta menjadikan anaknya sebagai kekuatan dirinya. Dukungan dari pihak guru-guru di sekolah dan dukungan dari pihak guru-guru di sekolah. Cara memecahkan masalah dalam mendidik Pendidikan Agama Islam. Memecahkan masalah dengan cara menasehati dengan menyentuh hati dan perasaan, selalu bersabar dan berdo'a, menanyakan segala masalah memecahkan masalah dengan mencari tahu penyebab dari masalah tersebut dan setelah itu mencari solusi yang tepat dan sesuai serta melakukan mediasi apabila melakukan kesalahan dan dimusyawarahkan terlebih dahulu tanpa melukai hati si anak.

\section{BIBLIOGRAPHY}

Ahmad, N. Q., \& Asdiana, A. (2019). UPAYA GURU PENDIDIKAN AGAMA ISLAM DALAM MENGHADAPI KENAKALAN REMAJA PADA MASA PUBERTAS. Jurnal As-Salam. https://doi.org/10.37249/as-salam.v3i2.127

Ahyadin, A., \& Ridwan, R. (2020). RAGAM DISFUNGSI DALAM KELUARGA DI KOTA BIMA. SANGAJI: Jurnal Pemikiran Syariah Dan Hukum. https://doi.org/10.52266/sangaji.v4i2.490

Ariani, A. I. (2019). Dampak Perceraian Orang Tua Dalam Kehidupan Sosial Anak. Phinisi Integration Review. https://doi.org/10.26858/pir.v2i2.10004

Aziz, M. (2019). PERILAKU SOSIAL ANAK REMAJA KORBAN BROKEN HOME DALAM BERBAGAI PERSPEKTIF (Suatu Penelitian di SMPN 18 Kota Banda Aceh). Jurnal AL-IJTIMAIYYAH: Media Kajian Pengembangan Masyarakat Islam, 1(1), 30-50. https://doi.org/10.22373/al-ijtimaiyyah.v1i1.252

Baharun, H. (2016a). Pendidikan Anak dalam Keluarga; Telaah Epistemologis. Jurnal Pedidikan, 3(2), 96-107.

Baharun, H. (2016b). Pendidikan Anak Dalam Keluarga; Telaah Epistemologis. PEDAGOGIK: JURNAL PENDIDIKAN, 3(2).

Chalim, S., Sujono, G., \& Usman, F. (2020). Trend Analysis Based Educator Planning. Naz̧runa: Jurnal Pendidikan Islam, 3(2), 273-284. https:// doi.org/10.31538/nzh.v3i2.683

Djaelani. (2013). Peran pendidikan agama islam dalam keluarga dan masyarakat. Jurnal Ilmiah WIDYA, 1(1).

Fajriana, A. W., \& Aliyah, M. A. (2019). Tantangan Guru dalam Meningkatan Mutu Pendidikan Agama Islam Di Era Melenial. Naz̧hruna: Jurnal Pendidikan Islam, 2(2), 246-265. https://doi.org/10.31538/nzh.v2i2.324

H. Tahang, J. (2010). Urgensi Pendidikan Agama Dalam Keluarga Terhadap Pembentukan Kepribadian Anak. HUNAFA: Jurnal Studia Islamika, 7(2), 163. https://doi.org/10.24239/jsi.v7i2.99.163-178

Hamzah, N. (2015). Pendidika Agama dalam Keluarga. At Turats, 9(2), 49-55.

Hasanah, M. (2020). Rekrutmen Dan Seleksi Tenaga Pendidikan (Guru) Untuk Meningkatkan Kualitas Pendidikan di SMA Unggulan Berbasis Pesantren Amanatul Ummah Pacet. AlTarbawi Al-Haditsah: Jurnal Pendidikan Islam, 5(1), Article 1. https://doi.org/10.24235/tarbawi.v5i1.6310

Hirdayadi, I., \& Susanti, H. (2018). DIVERSI DALAM SISTEM PERADILAN PIDANA ANAK DI INDONESIA DAN TINJAUANNYA MENURUT HUKUM ISLAM. LEGITIMASI: Jurnal Hukum Pidana Dan Politik Hukum. https://doi.org/10.22373/legitimasi.v6i2.3954

Komariah, K. S. (2019). Model Pendidikan Nilai Moral Bagi Para Remaja Menurut Perspektif Islam. Jurnal Pendidikean Agama Islam-Ta'lim, 9(1), 45-54.

Lestari, T. A., Ma'arif, M. A., Kartiko, A., Karim, A., \& Siregar, B. (2021). Mental Revolution of Homeless Children's Through Islamic Education Learning. 67-72. https://doi.org/10.2991/assehr.k.210421.011 
Ma'arif, M. A. (2017). Analisis Konsep Kompetensi Kepribadian Guru PAI menurut Az-Zarnuji. Istawa: Jurnal Pendidikan Islam. https://doi.org/10.24269/ijpi.v2i2.624

Ma'arif, M. A., \& Cahyani, I. (2019). Pendidikan Multikultural Sebagai Pembentukan Karakter Peserta Didik. TA'LIM : Jurnal Pendidikan Agama Islam.

Masnunah, M. (2018). Media Realia dan Media Maya Dalam Pembelajaran Agama Islam Di Sd. Wahana Sekolah Dasar. https://doi.org/10.17977/um035v26i22018p051

Mutmainah, H., \& Mufid, M. (2018). UPAYA GURU PAI DALAM PENINGKATAN KECERDASAN EMOSIONAL DAN SPIRITUAL PESERTA DIDIK DI SMAN 1 BOJONEGORO. At-Tubfah. https://doi.org/10.36840/jurnalstudikeislaman.v7i1.118

Noer, M. A., \& Sarumpaet, A. (2017). Konsep Adab Peserta Didik dalam Pembelajaran menurut Az-Zarnuji dan Implikasinya terhadap Pendidikan karakter di Indonesia. Al-Hikmah: Jurnal Agama Dan Ilmu Pengetabuan, 14(2), 181-208.

Nugroho, P. (2018). Paradigma Pendekatan Spiritual dalam Layanan Bimbingan dan Konseling di Lembaga Pendidikan Islam. KONSELING EDUKASI 'Journal of Guidance and Counseling'. https://doi.org/10.21043/konseling.v1i1.3620

Nurulloh, A., Aprilianto, A., Sirojuddin, A., \& Maarif, M. A. (2020). THE ROLE OF THE HEAD OF MADRASAH'S POLICY IN IMPROVING TEACHER PROFESSIONALISM. Nidhomul Haq: Jurnal Manajemen Pendidikan Islam, 5(3), 334-346. https://doi.org/10.31538/ndh.v5i3.963

Rofi'ah. (2020). Meningkatkan Motivasi Belajar Pendidikan Sejarah Kebudayaaan Islam Melalui Metode Pembelajaran Mind Mapping. Attadrib: Jurnal Pendidikan Guru Madrasab Ibtidaiyah, 3(2), 33-40. http://www.jurnal.staidagresik.ac.id/index.php/attadrib/article/view/109

Setiani, B. (2013). Kajian Sumber Daya Manusia Dalam Proses Rekrutmen Tenaga Kerja Di Perusahaan. Jurnal Ilmiah Widya, 1(1), 38-44.

Shofwatal Qolbiyyah. (2017). Kenakalan Remaja (Analisis Tentang Faktor Penyebab dan Solusinya dalam Perspektif Pendidikan Agama Islam). Sumbula: Jurnal Studi Keagamaan, Sosial Dan Budaya.

Sugiyono. (2014). Metode penelitian Kuantitatif Kualitatif dan R\&D (Ed. 14). Alfabeta.

Surur, A. M. (2018). Upaya Menanamkan Nilai Religius Siswa Di Man Kediri 1 Kota Kediri Dengan Ekstrakurikuler Keagaman Tahfidz Al-Qur'an. Jurnal Pendidikan Agama Islam, 15(1), 42-51. https://doi.org/10.14421/jpai.2018.151-03

Tindagi, M. G. K. (2017). Indikator Penanaman Nilai-Nilai Pak Dalam Keluarga Bagi Perbinaan Iman Anak Remaja Di Zaman Now. Missio Ecclesiae.

Usu, U. S., Lahaji, \& Damhuri. (2020). Peran Guru Pendidikan Agama Islam Dalam Mengatasi Kenakalan Remaja Di SMKN 1 Bone Raya Kabupaten Bonebolango. Irfani. https://doi.org/10.30603/ir.v15i2.1169

Widyastuti Gintulangi, Jusdin Puluhulawa, Z. N. (2019). Dampak Keluarga Broken Home Pada Prestasi Belajar Pkn Siswa Di Sma Negeri I Tilamuta Kabupaten Boalemo. 53(9), 1689-1699.

Yaqin, M. A. (2016). PENDIDIKAN AGAMA ISLAM DAN PENANGGULANGAN KENAKALAN SISWA (Studi Kasus MTs Hasanah Surabaya). Jurnal Pendidikan Agama Islam Journal of Islamic Education Studies), 4(2), 293. https://doi.org/10.15642/pai.2016.4.2.293-314

Zulaikhah, D., Sirojuddin, A., \& Aprilianto, A. (2020). Analisis Pembelajaran Pendidikan Agama Islam Kurikulum 2013 Bagi Anak Berkebutuhan Khusus. Tafkir: Interdisciplinary Journal of Islamic Education, 1(1), 54-71. https://pasca.jurnalikhac.ac.id/index.php/tijie/article/view/6 